\title{
Gastrointestinal helminths of Gentoo penguins (Pygoscelis papua) from Stranger Point, 25 de Mayo/King George Island, Antarctica
}

\author{
Julia Inés Diaz • Bruno Fusaro $\cdot$ Lucrecia Longarzo • \\ Néstor Rubén Coria • Virginia Vidal • Silvia Jerez • \\ Juana Ortiz • Andrés Barbosa
}

Received: 15 November 2012 / Accepted: 3 February 2013 /Published online: 23 February 2013

(C) Springer-Verlag Berlin Heidelberg 2013

\begin{abstract}
The aim of this work is to contribute to the knowledge of gastrointestinal parasites of the Gentoo penguin (Pygoscelis papua) from 25 de Mayo/King George Island (South Shetlands, Antarctica). Gastrointestinal tracts of 37 fresh dead individuals ( 21 chicks, 10 juveniles, and 6 adults) were collected from December 2006 to February 2012 and examined for macroparasites. Four adult parasite species were found: one Cestoda species (Parorchites zederi), two Nematoda species (Stegophorus macronectes and Tetrameres wetzeli), and one Acanthocephalan (Corynosoma shackletoni). Two species of immature acanthocephalans, Corynosoma hamanni and Corynosoma bullosum, were found in a single host. This is the first record of
\end{abstract}

\section{J. I. Diaz $(\bowtie) \cdot$ B. Fusaro $\cdot$ L. Longarzo}

Centro de Estudios Parasitológicos y de Vectores (CCT La

Plata-CONICET-UNLP), Calle 2 No. 584,

1900 La Plata, Buenos Aires Province, Argentina

e-mail: jidiaz@cepave.edu.ar

\section{N. R. Coria}

Departamento Biología de Predadores Tope, Instituto Antártico

Argentino, DNA, Balcarce,

C1064AAF Buenos Aires, Argentina

V. Vidal $\cdot$ J. Ortiz

Departamento de Sanidad Animal (Parasitología), Facultad

de Veterinaria, Universidad de Murcia, Espinardo,

30100 Murcia, Spain

\section{S. Jerez}

Área de Toxicología, Facultad de Veterinaria, Universidad de Murcia, Campus de Espinardo,

30100 Murcia, Spain

\section{A. Barbosa}

Departamento de Ecología Evolutiva, Museo Nacional de Ciencias Naturales (CSIC), C/José Gutierrez Abascal, 2,

Madrid 28006 Spain
Tetrameres wetzeli in Gentoo penguins. The low parasite richness observed could be related to the stenophagic and pelagic diet of this host species which feeds almost exclusively on krill.

\section{Introduction}

Although almost all animal populations are affected by some kind of parasites, major environmental changes, often the product of human activities, can affect ecosystems and result in an increase directly or indirectly in the distribution, abundance, or virulence of parasites and pathogens (Kerry et al. 1999; Barbosa and Palacios 2009; Fonteneau et al. 2011). Changes caused by El Niño events have been demonstrated to exert an influence over marine and terrestrial parasites (Daszak et al. 2000). Therefore, it is important to document the occurrence of new diseases that could be contracted by changes in diet composition as a product of climate change (Lozano 1991) and could result in declination or extinction of endemic populations (Warner 1968). Information about distribution of parasites and endemic diseases is fundamental, as well as the understanding of modulations that they can cause in animal populations (Fonteneau et al. 2011).

Penguins are excellent models to measure the effect of climate changes because they are very sensitive to changes in the ocean ecosystem (Boersma 2008), and this should be reflected in their parasites. Also, they inhabit a wide geographic area (Barbraud and Weimerskirch 2006), and in Antarctica, penguins are a high proportion of the vertebrate biomass.

The Gentoo penguin, Pygoscelis papua (Forster) (Aves, Spheniscidae), is one of the more abundant marine birds in the Antarctic ecosystem (Croxall and Prince 1980) and has a circumpolar distribution, between $46^{\circ}$ and $65^{\circ}$ on Sub- 
Antarctic islands and the Antarctic Peninsula (Woelher 1993). Adults begin to arrive on coasts in late September, and the breeding season takes place until February. Despite Gentoo penguins feeding extensively on krill, they are capable of a high plasticity in their diet, including also fishes and squids (Berón et al. 2002, Miller et al. 2009, Libertelli et al. 2010), which allows them to adapt to unfavorable conditions. In fact, this species is increasing its populations on the Antarctic Peninsula unlike the other two species of pygoscelid penguins (Lynch et al. 2012).

Knowledge about the parasites and diseases of P. papua in its Antarctic distribution range is very scarce (Kerry et al. 1999; Barbosa and Palacios 2009). Recent research has enlarged considerably the knowledge about parasites of some Antarctic penguins, providing not only taxonomic information but also data on prevalence and intensity (Fonteneau et al. 2011; Vidal et al. 2012). Data on the helminth fauna of the Gentoo penguin, however, is fragmented, outdated, includes erroneous identifications, and in some cases, is based on sporadic findings (Cielecka et al. 1992; Fredes et al. 2006; Barbosa and Palacios 2009; Woods et al. 2009).

The objective of the present study is to describe the gastrointestinal helminth community of Pygoscelis papua from Stranger Point, 25 de Mayo/King George Island, Antarctica, with the ultimate goal of providing baseline data for the parasite/host relationships in this host species and locality which may be sensitive to environmental changes which are currently occurring due to climatic change in the region (Turner et al. 2009).

\section{Materials and methods}

Thirty seven Gentoo penguins, Pygoscelis papua -21 chicks (less than 20 days old), 10 juveniles (more than 20 days old), and 6 adults - freshly dead, were collected in the Antarctic Specially Protected Area 132, Stranger Point (62 ${ }^{\circ} 14^{\prime}$ S$58^{\circ} 39^{\prime} \mathrm{W}$ ), near the Argentinean Scientific Base Carlini, 25 de Mayo/King George Island, South Shetland Islands, Antarctica, during summer field trips from 2006 to 2012, except 2010/2011. Digestive tracts were removed and frozen at $-20{ }^{\circ} \mathrm{C}$ or fixed in $10 \%$ formalin until parasitological examination could be carried out. They were separated into esophagus, stomach, and intestine. Gastrointestinal helminths were removed under a stereomicroscope, fixed in $5 \%$ hot formalin, and preserved in $70 \%$ ethanol. Cestodes were stained in Semichon's carmine, dehydrated in a graded ethanol series, cleared in methyl salicylate, and mounted in Canada balsam. Some specimens were embedded in paraffin, sectioned in transversal and sagittal views of $8-10-\mu \mathrm{m}$ thickness, and stained in haematoxylin-eosin. Nematodes were cleared in $25 \%$ glycerine alcohol and acanthocephalans in lactophenol. All species were studied using a light microscope. Some specimens of each species collected were dehydrated, dried by the critical point method; gold coated, observed, and photographed using a scanning electron microscope (JEOL/JSMT 6360 LV, Tokyo, Japan) from the Museo de La Plata, La Plata, Argentina. The terms prevalence $(P)$, mean intensity (MI), and community were interpreted and calculated according to Bush et al. (1997). The MI is followed by standard error and range. Specimens were deposited in the Helminthological Collection of the Museo de La Plata (MLP) 6653, 6654, 6655, 6656, La Plata, Argentina and Museo Nacional de Ciencias Naturales de Madrid (MNCN) 4.03/164, $11.02 / 4,11.02 / 5,13.03 / 2$.

\section{Results}

A total of 836 helminths were recovered, belonging to four parasite species: one cestode Parorchites zederi (Baird 1853) from the intestine; two nematode species, Stegophorus macronectes (Johnston and Mawson 1942) in the esophagus and stomach, and Tetrameres wetzeli Schmidt 1965 in the glandular stomach; and one acanthocephalan, Corynosoma shackeltoni (Zdzitowiecki 1978) in the intestine. Also, immature acanthocephalans belonging to two different species of Corynosoma were found. Of the total penguins examined, $62.2 \%$ were parasitized by at least one of the species identified $(\mathrm{MI}=36.3)$.

Parorchites zederi (Cestoda, Dilepididae) (Fig. 1) was localized free in the intestinal content or deeply embedded in the intestinal mucosa forming nodular lesions with different morphology. The scolex has four suckers and a rostellum armed with 18-20 hooks disposed in two rows and is followed by a large and wide pseudoscolex. Mature proglottids are wider than long. Genital pores are irregularly alternate.

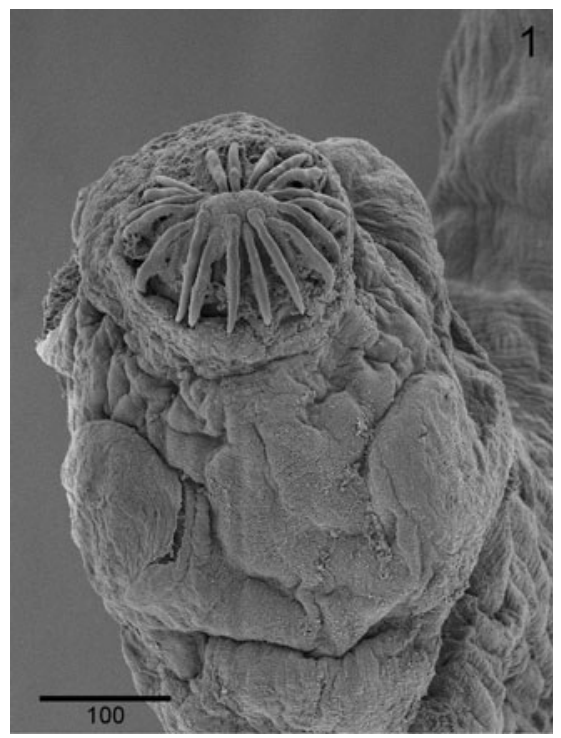

Fig. 1 Parorchites zederi, scolex 
Stegophorus macronectes (Nematoda, Acuariidae) (Fig. 2) was located in the stomach. The identification was based on the study of the morphology of ornamental cephalic structures, cephalic collar and deirids, papillae distribution and features of spiculae in males, and position of the vulva in females.

In this work, a large number of gravid females of Tetrameres wetzeli (Nematoda, Tetrameriidae) (Fig. 3) were found in glands; however, only a few immature males were found.

Adult acanthocephalans were found in the intestine. Taking into account the number, shape, and size of hooks, size of proboscis, lemnisci shape, relation between proboscis receptacle and lemnisci, distribution of trunk spines, and lengths of eggs, they were identified as Corynosoma shackletoni (Fig. 4). Also, immature acanthocephalan specimens identified as Corynosoma hamanni (Linstow 1892) and Corynosoma bullosum (Linstow 1892) were found in one penguin host.

Parorchites zederi and Stegophorus macronectes were the most common parasites in the studied community $(P=54 \%$; $\mathrm{MI}=8.3 \pm 3.4,1-70$ and $P=48.6 \%$; $\mathrm{MI}=31 \pm 9.4,1-121$, respectively). Tetrameres wetzeli had a very low prevalence $(P=5.4 \%)$ although the mean intensity was comparatively high (MI $=35 \pm 9,26-44)$. Corynosoma shackletoni was also uncommon $(P=13.5 \%$; MI $=7.4 \pm 3,3-19)$.

Overall, prevalence, mean intensity, and species richness in chicks were low $(P=38.8 \%$; MI $=6 \pm 1.7,1-15$; usually one species per host, $P$. zederi or $S$. macronectes). In contrast, all juvenile and adult hosts were parasitized, showing the highest prevalence and intensities $(P=100 \%$; MI $=51 \pm$ $17.7,1-153$ and $P=100 \%$; MI $=46 \pm 18,1-109$, respectively), as well as richness ( $2-3$ species per host). All parasites species were registered in juveniles and adults and

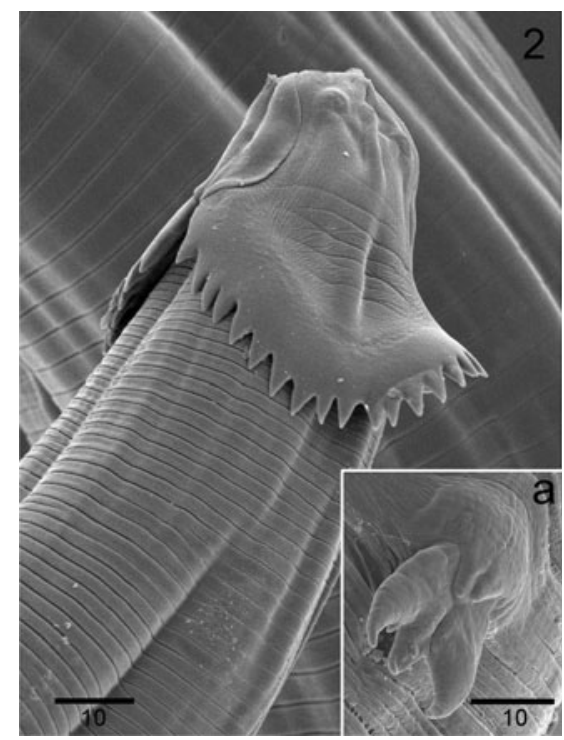

Fig. 2 Stegophorus macronectes anterior end, showing detail of deirid (a)

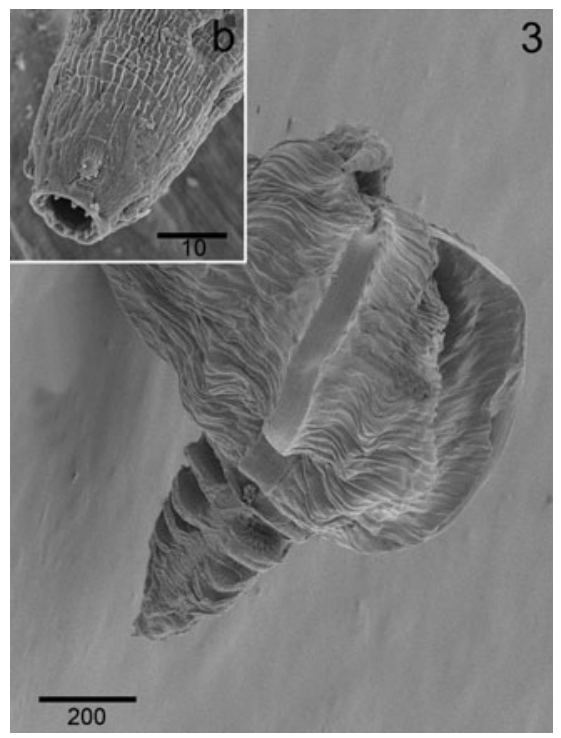

Fig. 3 Tetrameres wetzeli female, showing detail of anterior end in apical view (b)

throughout all the study period, except $T$. wetzeli that was found only in juveniles in February.

\section{Discussion}

The component community of Pygoscelis papua in this study was composed of four helminth species. Cestodes of the species $P$. zederi penetrate the intestinal mucosa reaching the intestinal serosa where they generate large nodules (Ippen et al. 1981; Tzvetkov et al. 1999). This species is widely distributed among Antarctic penguins (Hoberg 2005; Barbosa and

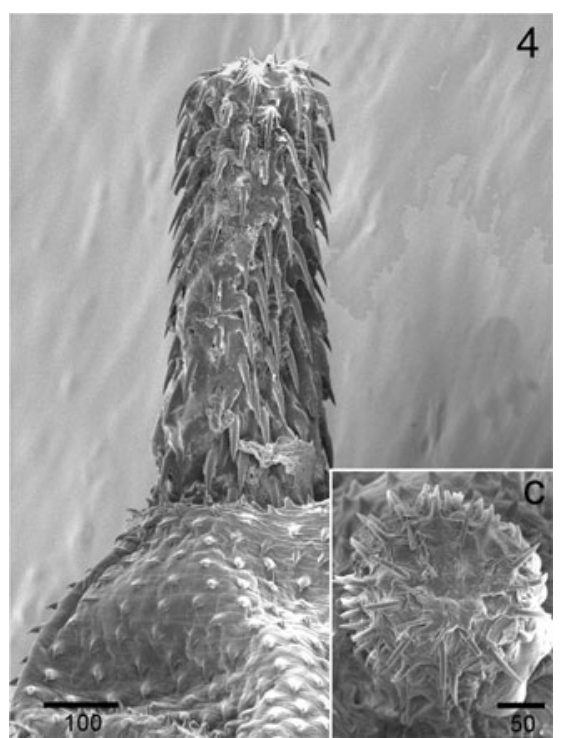

Fig. 4 Corynosoma sp. proboscis, showing detail of hooks (c) in apical view 
Palacios 2009; Vidal et al. 2012) and is the only member of the order Cyclophyllidea in pelagic systems (Hoberg 2005).

The nematode Stegophorus macronectes has a wide host and geographical distribution (Vidal et al. 2012). Among penguins this species has been reported in P. papua, Pygoscelis adeliae (Hombron and Jacquinot), Pygoscelis antarctica (Forster), Eudyptes chrysocome (Forster) and Eudyptes chrysolophus (Brandt) (Johnston and Mawson 1945; Mawson 1953; Zdzitowiecki and Drózdz 1980).

Tetrameres wetzeli was described from a Rockhopper penguin E. chrysocome at a German zoo that had original been collected on the Kerguelen Islands (Schmidt 1965) and more recently in the King penguin, Aptenodytes patagonicus Miller, in the Crozet Islands (Fonteneau et al. 2011). The genus Tetrameres parasitizes different orders of birds in which typically both female and male are found together in the glands of the proventriculus wall, and usually, the male migrates to the digestive cavity when the cyst breaks (Schmidt 1965). Because this species is hidden in the proventricular glands, it is possible that its presence has been undetected or underestimated in previous works. Even so, we cannot affirm that it was a component species of the helminth community of this colony. It is possible that a temporal variation in the diet has caused this new infestation. However, further studies are necessary to corroborate if this is a change in the helminth community of this host population, expanding the distribution range of this nematode, or if it is an isolated record.

Among seabirds, nematodes are often characteristic, prominent, and abundant components of the overall parasite fauna, with spirurids such as species of Stegophorus and Tetrameres characteristic in penguins (Hoberg 2005).

Many species of Corynosoma that are found in seabirds only develop to maturity in cetaceans or pinnipeds (Hoberg 2005). Most of the reports of the genus in marine birds have been of immature specimens (Zdzitowiecki 1984, 1985, 1986, 1991; Vidal et al. 2012). Birds frequently act as an ecological sink of seal parasites, ending up in hosts where they cannot reproduce (Taraschewski 2005). Only Corynosoma shackletoni has been found in the adult stage in pygoscelid penguins, precisely in Gentoo penguins (Hoberg 1986).

The higher values of prevalence, intensities, and richness in both adults and juveniles birds are probably because the older hosts had more time to accumulate parasites. The high prevalence of P. zederi and S. macronectes in Gentoo penguin may be a consequence of the broad oceanic distribution of euphausiids that serve as suitable intermediate/paratenic hosts and are the principal prey items of this penguin in the study area (Williams 1995). The pelagic crustacean Euphausia superba (krill) appears to be the main intermediate host for $P$. zederi and $S$. macronectes, but not for $C$. shackletoni (see Anderson 2000, Hoberg, 2005, Vidal et al., 2012). In contrast, $C$. shackletoni were being acquired by feeding in littoral habitat from piscine prey. It is known that notothenid fishes as
Notothenia coriiceps harbor cystacanths of $C$. shackletoni in the studied area (Laskowski and Zdzitowiecki 2005; Laskowski et al. 2012). As was stated by Fonteneau et al. (2011), "further studies should be conducted to determine possible sources of infestation by the nematode $T$. wetzeli."

Barbosa and Palacios (2009) reported other helminth species present in the Gentoo penguin in other places in Antarctica (e.g., Contracaecum heardi, Stomachus sp., Streptocara sp., Ascaridia sp., Tetrabothrius pauliani, and Corynosoma bullosum (Mawson 1953; Prudhoe 1969; Hoberg 1986; Fredes et al. 2006, 2007)). Almost all these records consisted of a few immature parasite specimens and could represent occasional and/or accidental findings, whereas the results here are based on a representative sample of the colony. However, variations in the species richness due to differences in the geographical areas considered between studies, sampling effort of helminths, changes in the diet, or in distribution of parasites cannot be excluded.

As expected in pelagic and stenophagic birds such as penguins, the helminth richness was low (Hoberg 2005; Barbosa and Palacios 2009; Diaz et al. 2010a; Fonteneau et al. 2011; Vidal et al. 2012). However, Gentoo penguins seems to harbor more helminth species than the Adélie or the chinstrap penguin (Barbosa and Palacios 2009; Vidal et al. 2012; Diaz et al. 2010b), probably due to their wider prey spectrum.

Nevertheless, our results might have been influenced by the large number of chicks in the sample, which may not have had enough time to acquire parasites. Also, there is a preferential prey selection during the breeding season. This could cause a bias on the global results. Also, taking into account that birds were found dead, it could not be excluded that causes of death were related to the parasite burden, overestimating the infestation rate population. Even so, baseline data is provided on the helminth fauna of Gentoo penguin in this habitat.

In spite of the low prevalence, this work highlights the first record of the genus Tetrameres in Gentoo penguin and also in Antarctica as other records have been reported for SubAntarctic Islands (Schmidt 1965; Fonteneau et al. 2011).

Acknowledgments We very much appreciate the hospitality and logistic support of the Argentinean Antarctic Base "Carlini." We especially thank the Argentinean transports and the Spanish Polar Ship "Las Palmas" which provided us transport to the Antarctic Base. We also thank the logistic support provided by the Instituto Antártico Argentino and the Maritime Technology Unit (CSIC). We thank Dr. John Mike Kinsella for English revision and the critical reading of the manuscript. Financial support was given by the Dirección Nacional del Antártico, the Spanish Ministry of Science and Innovation, and European Regional Development Fund (projects CGL2004-01348, POL200605175, and CGL2007-60369). Permission to work in the Antarctic study area and for penguin handling was given by Dirección Nacional del Antártico and the Spanish Polar Committee. JID is partially supported by PICT309 (ANPCyT) and N628 (UNLP). VV was supported by a PhD grant from the Spanish Council of Scientific Research (JAEPre08-01053). This is a contribution to the International Polar Year project 172 BirdHealth and to PINGUCLIM project. 


\section{References}

Anderson RC (2000) In: CAB International (ed) Nematode Parasite of Vertebrates. Their development and Transmission, 2nd edn. Oxon, Wallingford,UK, $650 \mathrm{p}$

Bush AO, Lafferty KD, Lotz JM, Shostak AW (1997) Parasitology meets ecology on its own terms: Margolis et al. revisited. J Parasitol 83:575-583

Barbosa A, Palacios MJ (2009) Health of Antarctic birds: a revision of their parasites, pathogens and diseases. Polar Biol 32:1095-1115

Barbraud C, Weimerskirch H (2006) Antarctic birds breed later in response to climate change. Proc Natl Acad Sci 103:6248-6251

Berón MP, Coria NR, Favero M (2002) Monitoreo de la dieta postreproductiva del pingüino Papua (Pygoscelis papua) en Isla Laurie (Orcadas Del Sur, Antartida): periodo 1997-1999. Ornitol Neotrop $13: 413-422$

Boersma PD (2008) Penguins as marine sentinels. Bioscience 58:597-607

Cielecka D, Wojciechowska A, Zdzitowiecki K (1992) Cestodes from penguins on King George Island (South Shetlands, Antarctic). Acta Parasitol 37:65-72

Croxall JP, Prince ED (1980) Food, feeding ecology and ecological segregation of seabirds at south Georgia. Biol J Linn Soc 14:103-131

Daszak P, Cunningham AA, Hyatt AD (2000) Emerging infectious diseases of wildlife: threats to biodiversity and human health. Science 287:443-449. doi:10.1126/science.287.5452.443

Diaz JI, Cremonte F, Navone GT (2010a) Helminths of the Magellanic penguin, Spheniscus magellanicus (Sphenisciformes), during the breeding season in Patagonian Coast, Chubut, Argentina. Comp Parasitol 77:172-177

Diaz JI, Fusaro B, Longarzo L et al (2010b) Parásitos gastrointestinales de pingüinos del género Pygoscelis en la isla 25 de Mayo. Antártida. Dissertation I Congreso Latinoamericano de Conservación de la Biodiversidad. Tafí del Valle, Tucumán, Argentina

Fonteneau F, Geiger S, Marion L, Le Maho Y, Robin JP, Kinsella JM (2011) Gastrointestinal helminths of King penguins (Aptenodytes patagonicus) at Crozet Archipelago. Polar Biol 34:1249-1252. doi:10.1007/s00300-011-0970-9

Fredes F, Raffo E, Muñoz P, Herrera M (2006) Fauna parasitaria gastrointestinal en polluelos de Pinguino Papua (Pygoscelis papua) encontrados muertos en zona antártica especialmente protegida (ZAEP No150). Paras Latin 61:179-182

Fredes F, Madariaga M, RaVo E, Valencia J, Herrera M, Godoy C, Alcaíno H (2007) Gastrointestinal parasite fauna of Gentoo penguins (Pygoscelis papua) from the Península Munita, Bahía Paraíso, Antarctica. Antarctic Sci 19:93-94

Hoberg EP (1986) Aspects of ecology and biogeography of Acanthocephala in Antarctic seabirds. Ann Parasit Hum Comp 61:199-214

Hoberg EP (2005) Economic, environmental and medical importance: marine birds and their helminth parasites. In: Rohde K (ed) Marine Parasitology. CSIRO, Sydney, Australia, pp 414-421

Ippen R, Odening K, Henne D (1981) Cestoden (Parorchites zederi) und Sarkosporidienbefall (Sarcocystis sp.) bei Penguinen der SlidShetland Inseln. Verhandl. des XXIII. Int. Symp. Erkrankungen Zootiere Halle/Saale. Akademischer Verlag Berlin, pp 203-210

Johnston TH, Mawson PM (1945) Parasitic nematodes. BANZARE V(2):73-160, Reports, Series B

Kerry K, Riddle M, Clarke K (1999) Diseases of Antarctic wildlife. A report for SCAR and COMNAP, SCAR

Laskowski Z, Zdzitowiecki K (2005) The helminth fauna of some notothenioid fishes collected from the shelf of Argentine Islands, west Antarctica. Pol Polar Res 26:315-324

Laskowski Z, Korczak-Abshire M, Zdzitowiecki K (2012) Changes in acanthocephalan infection of the Antarctic fish Notothenia coriiceps in Admiralty Bay, King George Island, over 29 years. Pol Polar Res 33:99-108

Libertelli MM, Juares MA, Santos MM, Favero M, Coria NR (2010) Variation in the diet of Gentoo Penguin at Cierva Point and Esperanza Bay (Antarctic Peninsula) and Stranger Point (South Shetland Islands). A report for SCAR, Antarctica, 24

Lozano GA (1991) Optimal foraging theory: a possible role for parasites. Oikos 60:391-395

Lynch HJ, Naveen R, Trathan PN, Fagan WF (2012) Spatially integrated assessment reveals widespread changes in penguin populations on the Antarctic Peninsula. Ecology 93:1367-1377

Mawson P (1953) Parasitic Nematoda collected by the Australian National Antarctic Research Expedition: Heard Island and Mcquarie Island, 1948-1951. Parasitology 43:291-297

Miller AK, Karnowsky NJ, Trivelpiece WZ (2009) Flexible foraging strategies of Gentoo penguins Pygoscelis papua over 5 years in the South Shetlands Islands, Antarctica. Mar Biol 156:2527-2537

Prudhoe S (1969) Cestodes from fish, birds and whales. British Australian New Zealand Antarctic Research Expedition Reports, Ser. B VIII, Part. 9

Schmidt H (1965) Tetrameres (G.) wetzeli sp. n. (Nematoda, Spirurida), eine neue Tetrameresart aus dem Felsenpinguin, Eudyptes (= Catarrhactes) chrysocome Forst (Aves, Sphenisciformes). Z f Parasitenkunde 26:71-81

Taraschewski H (2005) Helminth parasites: Acanthocephala (thorny or spiny-headed worms). In: Rohde K (ed) Marine Parasitology. CSIRO, Sydney, Australia, pp 116-122

Turner J, Bindschadler R, Convey P, di Prisco G, Fahrbach E, Gutt J, Hogdson D, Mayewski P, Summerhayes C (2009) Antarctic climate change and the environment. SCAR, Cambridge UK

Tzvetkov Y, Kril A, Georgiev BB, Chipev NH (1999) Morphology of lesions in the intestinal wall of the Gentoo penguin, Pygoscelis papua, caused by Parorchites zederi (Cestoda: Dilepididae). In: Golemansky V, Chipev N (eds) Bulgarian Antarctic Research. Life Sciences, 2nd edn. Pensoft Publishers, Sofia and Moscow, pp 62-67

Vidal V, Ortiz J, Diaz JI et al (2012) Gastrointestinal parasites in chinstrap penguins from Deception Island, South Shetlands, Antarctica. Parasitol Res 111:723-727. doi:10.1007/s00436-012-2892-z

Warner RE (1968) The role of introduced diseases in the extinction of the endemic Hawaiian avifauna. Condor 70:101-120

Williams TD (1995) The penguins. Spheniscidae. (Birds Families of the Word, No 2). Oxford University Press. $328 \mathrm{p}$

Woelher EJ (1993) The distribution and abundance of Antarctic and subantarctic penguins. Scientific communication on Antarctic Research, Cambridge, pp 11-13

Woods R, Jones HI, Watts J, Miller GD, Shellam GR (2009) Diseases of Antarctic seabirds. In: Kerry KR, Riddle MJ (eds) Health of Antarctic wildlife: a challenge for science and policy. Biomedical and Life science (subject collection). Springer-Verlag, Berlin, Heidelberg, pp 35-55

Zdzitowiecki K (1984) Some Antarctic acanthocephalans of the genus Corynosoma parasitizing Pinnipedia, with descriptions of three new species. Acta Parasitol 29:359-377

Zdzitowiecki K (1985) Acanthocephalans of the birds from South Shetlands (Antarctic). Acta Parasitol 30:11-24

Zdzitowiecki K (1986) Acanthocephalans of the Antarctic. Acta Parasitol 78-117

Zdzitowiecki K (1991) Synopses of the Antarctic Benthos Koenigstein Koeltz Scientific Books. Antarctic Acanthocephala, Koenigstein, Alemania, $116 \mathrm{pp}$

Zdzitowiecki K, Drózdz J (1980) Redescription of Stegophorus macronectes (Johnston et Mawson, 1942) and description of Stegophorus arctowskii sp. n. (Nematoda, Spirurida) from birds of South Shetlands (the Antarctic). Acta Parasitol 26:205-212 